\title{
LncRNAs expression signatures of cadmium- induced malignant transformation of human bronchial epithelial cells revealed by microarray
}

\author{
Zhi-heng Zhou*, Cai-xia Wang², Yi-xiong Lei', Hai-bai Liu', Min Wang \\ From Epigenetics and Chromatin: Interactions and processes \\ Boston, MA, USA. 11-13 March 2013
}

\section{Background}

Cadmium (Cd) and its compounds are well-known environmental carcinogens, but the mechanisms underlying the carcinogenesis are not entirely understood yet. Long noncoding RNAs (IncRNAs) are an important class of pervasive genes involved in a variety of biological functions. They are aberrantly expressed in many types of cancers. In this study, we described IncRNAs profiles in $35^{\text {th }}$ passage of $\mathrm{CdCI}_{2}$ malignant transformation cells $\left(35^{\text {th }}\right.$ cell $)$ and untransformed human bronchial epithelial cells $(16 \mathrm{HBE})$ by microarray.

\section{Methodology/principal findings}

With abundant and varied probes accounting 33,045 LncRNAs in our microarray, the number of IncRNAs that expressed at a certain level could be detected is 21409 . From the data we found there were 369 IncRNAs were upregulated and 90 IncRNAs were downregulated $(\geq 2.0$ fold-change, $\mathrm{P}<0.05)$ in $35^{\text {th }}$ cells compared with $16 \mathrm{HBE}$ cells. Our data showed that upregulated IncRNAs were more common than downregulated ones. ENST00 000477387, ENST00000394732, ENST00000485873, ENST00000497538, uc002odz.1, AK023660, NR_023938, BC019085 were evaluated by qPCR in 35th cells compared with $16 \mathrm{HBE}$ cells. The eigth IncRNAs were aberrantly expressed in 35th cells compared with matched $16 \mathrm{HBE}$ cells.

\section{Conclusions/significance}

Our study is the first one to determine genome-wide IncRNAs expression patterns in Cadmium-induced malignant transformation by microarray. The results displayed

'School of public health, Guangzhou Medical University, Guangzhou 510182, People's Republic of China

Full list of author information is available at the end of the article that clusters of IncRNAs were aberrantly expressed in $\mathrm{CdCI}_{2}$ malignant transformation cells compared with $16 \mathrm{HBE}$ cells, which revealed that IncRNAs differentially expressed in $\mathrm{CdCI}_{2}$ malignant transformation cells may exert a partial or key role in cadmium-induced cancers. Taken together, this study may provide a viable mechanism for cadmium-induced cancers.

\section{Author details}

'School of public health, Guangzhou Medical University, Guangzhou 510182, People's Republic of China. ${ }^{2}$ Department of Internal Medicine of the First Hospital of Guangzhou, Guangzhou 510180, China.

Published: 18 March 2013

doi:10.1186/1756-8935-6-S1-P90

Cite this article as: Zhou et al.: LncRNAs expression signatures of cadmium-induced malignant transformation of human bronchial epithelial cells revealed by microarray. Epigenetics \& Chromatin 2013 6(Suppl 1):P90.

Submit your next manuscript to BioMed Central and take full advantage of:

- Convenient online submission

- Thorough peer review

- No space constraints or color figure charges

- Immediate publication on acceptance

- Inclusion in PubMed, CAS, Scopus and Google Scholar

- Research which is freely available for redistribution 